\title{
The influence of non-governing law on the interpretation of contracts in the United States
}

\section{Pieter Wolters}

To cite this article: Pieter Wolters (2015) The influence of non-governing law on the interpretation of contracts in the United States, Journal of Private International Law, 11:3, 505-541, DOI:

10.1080/17441048.2015.1103593

To link to this article: http://dx.doi.org/10.1080/17441048.2015.1103593

\section{曲 Published online: 23 Nov 2015.}

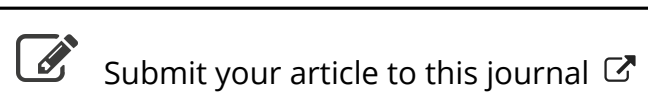

Џlll Article views: 75

Q View related articles $₫$

View Crossmark data $\asymp$ 


\title{
The influence of non-governing law on the interpretation of contracts in the United States
}

\begin{abstract}
Pieter Wolters*
In a globalized world, the parties and the contract are often "connected" to a law or jurisdiction that is different from the forum. In the current literature, the question of whether this law should influence the interpretation of such a contract has been approached from a conflict of laws perspective. However, this approach does not explain the influence of the "non-governing" law when this law is not applied. After all, the conflict of laws rule might lead to the application of another law. This paper shows that the non-governing law can influence the interpretation of a contract. Non-governing law can be connected to the contract, or to the parties to the contract, in various ways. In these situations, a court can consider non-governing law to better vindicate the intention of the parties. Furthermore, non-governing law can also influence the interpretation "through" other circumstances. Moreover, the influence of non-governing law is not significantly different from the influence of several more established circumstances. The influence of nongoverning law on the interpretation of a contract is limited to situations wherein the relevant conflict of laws rules do not lead to the application of the connected non-governing law. However, within this scope, the ability to consider non-governing law is a useful tool that is superior to the "conflicts of law approach".
\end{abstract}

Keywords: contracts; interpretation of contracts; intention; non-governing law; Islamic law; Jewish law; Restatement (Second) of Conflict of Laws; Restatement (Second) of Contracts

\section{A. Introduction}

In the various jurisdictions of the United States, the interpretation of a contract depends on the circumstances of the case. ${ }^{1}$ Some sources even state that all the

*LL.B., LL.M. and Ph.D., Radboud University; LL.M., University of Michigan Law School. Researcher and Lecturer at the Business \& Law Research Centre of the Radboud University (Nijmegen, The Netherlands). Email: p.wolters@jur.ru.nl. The author wishes to thank the two anonymous referees but acknowledges that any errors or omissions are his own responsibility.

${ }^{1}$ See, eg, Myers v Gulf Coast Minerals Mgmt Corp, 361 S.W.2d 193, 196 (Tex. 1962); Randallstown Plaza Associates v United States, 13 Cl. Ct. 703, 709 (1987); Watkins v Ford, 304 P.3d 841, 847 (Utah 2013); Restatement (Second) of Contracts § 202(1); JE Murray, Murray on Contracts (Michie, 4th edn, 2001) 479-480; SJ Burton, Elements of Contract Interpretation (Oxford University Press, 2009) 5. 
circumstances can be relevant. ${ }^{2}$ However, this influence of all (relevant) circumstances is not reflected in the current literature on the interpretation of contracts. Generally, the literature only analyses the role of certain circumstances. ${ }^{3}$ A thorough or systematic analysis of all the circumstances that influence the interpretation of a contract is lacking.

This paper explores the relevance of a circumstance that has been overlooked in the current literature on contract interpretation. In a globalized world, the parties or the contract are often "connected" to a law or jurisdiction that is different from the forum. The question of whether this law should influence the interpretation of such a contract can be approached from a conflict of laws perspective. ${ }^{4}$ The forum can apply the connected law when interpreting the contract. However, this approach does not explain the influence of the connected law when this law is not applied. The conflict rule might lead to the application of another law. After all, even if the contract has some connections with a particular legal system, the connections with another law might be stronger. This paper explores the influence of "non-governing law" on the interpretation of contracts. It will answer the following question: "can non-governing law influence the interpretation of contracts?"

Before answering this question, it is important to establish various definitions. Law is "non-governing" if it is different from the law that is applicable under the relevant conflict of laws rules. It is non-governing if it is from a state or country whose law does not govern (the interpretation of) the contract. To clarify, the forum and the parties do not determine whether a law is "non-governing". It is solely decided by the applicable conflict of laws rules. In other words, law is "non-governing" if it is different from the lex causae, even if it is the lex fori. For example, if a contract is governed by the law of Michigan, the law of

\footnotetext{
${ }^{2}$ See, eg, Krimlofski v United States, 190 F. Supp. 734, 741 (N.D. Iowa 1961); Steckler v Continental Oil Co, 154 So. 2d 647, 651-52 (La. Ct. App. 1963); Pacific Gas \& Elec Co v GW Thomas Drayage \& Rigging Co, 69 Cal. 2d 33, 39 (1968); Restatement (Second) of Contracts $\S 202(1)$; Murray, supra n 1; 5 MN Kniffin, Corbin on Contracts (Vol 5, Joseph M Perillo (ed), Lexis, 1998) 64.

${ }^{3}$ See, eg, Kniffin, supra n $2, \S 24.10, \S 24.13, \S 24.16-17, \S 24.20-21$; Burton, supra $\mathrm{n} 1$, at $37-57$. Various circumstances are mentioned and analyzed in sections D and F.

${ }^{4}$ See, eg, Restatement (Second) of Conflict of Laws § 188(1) (the "most significant relationship" test); Michael H Hoffheimer, "Conflicting Rules of Interpretation and Construction in Multi-Jurisdictional Disputes", (2011) Rutgers Law Review599.

${ }^{5}$ The term "foreign law" is also used. Shamil Bank of Bahrain EC v Beximco Pharmaceuticals Ltd (No1) [2004] 1 WLR 1784, 1799; U Magnus, "The Germanic Tradition: Application of Boilerplate Clauses under German Law", in G Cordero-Moss (ed) Boilerplate Clauses, International Commercial Contracts and the Applicable Law (Cambridge University Press, 2011) 179, 190; IS Zykin, "The East European Tradition: Application of Boilerplate Clauses under Russian Law" in Cordero-Moss (ed), ibid, 329, 331. This term is appropriate in most of the situations that are discussed in this paper. However, it can be confusing if the lex causae is different from the lex fori. In that context, the lex causae could be considered "foreign", even though it is not "non-governing".
} 
New York is non-governing even if the parties to the contract and the court that is resolving the dispute are located in New York.

Conflict of laws rules may prevent a rule from becoming a relevant "non-governing" law. In many cases, the connected law will also be the applicable law, even if it is different from the law of the forum. For this reason, non-governing law will only influence the interpretation of contracts in extraordinary situations. It will only influence the interpretation if it is relevant but not applicable.

This paper only discusses law that is "horizontal". The law is "horizontal" if it is not superior or inferior to the governing law. Federal law and treaties fall outside the scope of this research, even if they are not directly applicable. "Law" refers to law as evidenced by statutes and regulations, but also to law that is evidenced by court decisions. Unwritten norms, such as cultural rules, usages or business practices, may be law if they are binding under the non-governing law.

Although this paper is about the interpretation of contracts in the various jurisdictions of the United States, it does discuss several cases from other countries. These cases provide additional examples of the influence of non-governing law. They show that non-governing law can influence the interpretation of a contract in a variety of situations. In each of these cases, the connected law affects the interpretation in a way that is similar to the interpretation of a contract in the United States. It influences the interpretation if it affects the intention of the parties. $^{6}$

The rest of this paper proceeds as follows. First, section B sketches two situations that will function as examples throughout the rest of the paper. Next, the paper explores the relationship between the interpretation of contracts and conflict of laws rules. It shows that considering non-governing law when interpreting the contract has independent value, even if conflict of laws rules could lead to the same result (section C). Section D gives a short overview of the interpretation of contracts in the United States. Courts give effect to the intention of the parties. Non-governing law can influence this intention in various situations (section E5). Section $\mathrm{F}$ analyses the relationship between non-governing law and circumstances that are discussed in the current literature on the interpretation of contracts. The paper ends with a conclusion (section G7).

\section{B. Two situations}

This section sketches two situations that will function as examples throughout the rest of the paper. These situations represent two distinct types of connections to the non-governing law. In the first case, the parties are connected to the non-governing law (section B1). In the second situation, the contract is connected (section

\footnotetext{
${ }^{6}$ About German law, see G Dannemann, "Common Law-Based Contracts under German Law", in Cordero-Moss (ed) supra n 5, 62, 69; Magnus, supra n 5, at $190 \mathrm{n} 86$. About Dutch law, see sections E1 and E2(d).
} 
B2). Finally, section B3 shows that it is also possible to imagine situations in which non-governing law could play a more subtle role.

\section{The non-governing law is connected to the parties - the Chinese cook ${ }^{7}$}

Shu and Lam are born in China but currently reside in State X. The parties come to an oral agreement: Shu will work as a cook in the restaurant "Lotus". About four times each week, Lam visits the restaurant and gives instructions. Every month, Lam pays Shu's salary in cash. After five months, Shu is fired by Lam. Shu sues Lam for unpaid salary. In court, Lam argues that there is no contract between him and Shu. His sister is the owner of the restaurant. According to Lam, the employment contract was formed between Shu and his sister. He claims that he was merely an agent for his sister. During the formation of the contract, Shu and Lam never discussed the ownership of the restaurant. Shu never even met Lam's sister. The case turns on a question of interpretation. How should the agreement be interpreted? Did Shu and Lam form an employment contract between themselves, or between Shu and Lam's sister?

According to the agency rules of State X, Lam had the authority to bind his sister. If the contract were formed between Shu and Lam's sister, Lam is not liable for the remaining salary. The residents of State X generally form employment contracts with a business or, if the business is not incorporated, with the owner of the business. This would support an interpretation in favour of Lam.

Shu argues that under Chinese norms, the employer is not necessarily the business or its owner. Generally, the employer is the person who gives instructions and pays salaries. These Chinese norms support Shu's interpretation: he formed an employment agreement with Lam. Should these Chinese norms be considered relevant?

\section{The non-governing law is connected to the contract - the new machine}

Developer and Investor are residents of State Y. They have a plan to develop and manufacture a new agricultural machine. The parties decide to start a joint venture. Developer has to design and test the machine while Investor supplies the necessary funds. Both parties are new to this industry. After some deliberation, they decide to modify a standard contract that is often used in State Z, the worldwide centre of the development of agricultural tools and machines. The contract contains a buy-out clause and other provisions that can be found in most agreements to form a joint venture. It also contains several provisions that are more specific to the development of agricultural machines. The agreement does not contain a choice of law

${ }^{7}$ This situation is based on a Dutch Supreme Court (HogeRaad) case: HR 18 November 1983, NJ 1984, 345 (Shu/Lam). 
clause. The law of State Y applies under the conflict of laws rules of both State Y and State $Z$.

After a few months, the parties experience a setback. A company in State Z developed a machine that performs many of the functions that the proposed machine is to perform. Developer states that he is no longer obligated to design the machine. After all, the agreement states that Developer may abandon the project if a "competing newly developed machine" is "sold in the agricultural market". Investor wants Developer to finish development so that he can recoup at least a part of his investment. The competing machine does not perform well in some weather conditions. This gives the proposed machine an advantage in certain markets. Furthermore, Investor argues that the competing machine is not yet "sold in the agricultural market".

The terms "competing newly developed machine" and "sold in the agricultural market" are ambiguous. They have no special meaning in the law of State Y. In contrast, State $\mathrm{Z}$ has developed extensive case law about the meaning of terms such as "competing newly developed machine". Furthermore, a regulatory agency of State Z has defined the meaning of "agricultural market". Are these definitions relevant to the interpretation of the contract in State Y?

\section{Asymmetrical relations to the non-governing law}

The previous subsections sketch two situations in which non-governing law can be relevant. In the first case, both parties are connected to the non-governing law. In the second case, both parties are not connected to the non-governing law, but the contract is. In both cases, the parties have a symmetrical relationship to the connected law. The non-governing law could also be relevant in situations in which the parties do not occupy a similar position. For example, it is possible that just one of the parties is connected to the non-governing law. Could this party argue that he understood a certain clause in the light of the connected law, even if the other party does not have a connection with that jurisdiction?

In such a case, the argument for granting influence to the non-governing law is not as strong as in the cases described in sections B1 and B2. One could argue that granting influence to the non-governing law unduly benefits the party that is connected to this law. After all, if the non-governing law does not support the argument of the connected party, the party still has the option to forego invoking the non-governing law, instead relying on the interpretation under the governing law. Furthermore, the "unconnected" party may not be able to prepare for the influence of the non-governing law. The unconnected party may not be able to know that the other party would understand certain clauses in the light of a non-governing law. Next, he can only understand how this non-governing law would influence the understanding of the other party after investigating the contents of this law. This would impose a burden on the unconnected party. The previous arguments do not mean that non-governing law can never influence the interpretation of contracts in such situations. However, they do show that the argument for this influence is weaker. 


\section{The relationship between the interpretation of contracts and conflict of laws rules}

The subsequent sections are primarily descriptive. They show that non-governing law can influence the interpretation of a contract under the current law. However, interpretation is not the only way in which non-governing law can influence the legal consequences of the contract. Conflict of laws rules can lead to the application of the non-governing law. In these situations, the non-governing law does not influence the interpretation of the contract. Instead, it governs the contract and its interpretation. In many, if not all, of the situations discussed in this paper, the courts could decide to simply apply the non-governing law. ${ }^{8}$

This paper discusses several types of connections to non-governing law. Several of them are also relevant under Restatement (Second) of Conflict of Laws. For example, the intention of the parties as to the governing law has significant influence, even without an explicit choice of law provision. ${ }^{9}$ Express references to laws or legal doctrines that are peculiar to a certain state can be used to prove that the parties wanted to apply the laws of that state. ${ }^{10}$ If no intent can be ascertained, section 188(1) of the Restatement (Second) of Conflict of Laws states that an issue is determined by the law which, with respect to that issue, has the most significant relationship to the transaction and the parties. One of the relevant contacts is the "domicil, residence, nationality, place of incorporation and place of business of the parties". ${ }^{11}$

This raises the question of whether it is necessary to consider the non-governing law when interpreting the contract. Could a conflict of laws analysis not lead to the same results? In contrast to the subsequent sections, this section adopts a normative approach. It shows that considering non-governing law when interpreting the contract has independent value, even if conflict of laws rules can lead to the consideration of the connected law.

First, by considering non-governing law during the interpretation of the contract, the court can give influence to the relevant non-governing law in additional situations. Even if conflict of laws rules could lead to the application of the connected law, they may not actually lead to the application of this law in a particular

\footnotetext{
${ }^{8}$ See, eg, n4, 73, 81, 86, 114; section E2(b). This is not meant to imply that the above issues are universally treated as conflict of laws issues. For example, E Rabel, The Conflict of Laws: A Comparative Study. Vol 2. Foreign Corporations: Torts: Contracts in General (Michigan Legal Studies, prepared by U Drobnig, 2nd edn, 1960) 535-536 expressly rejects this approach.

${ }^{9}$ Restatement (Second) of Conflict of Laws $\S 187$, comment a, $\S 188$, reporter's note; Mayo v Hartford Life Ins Co, 354 F.3d 400, 404 (5th Cir 2004).

${ }^{10}$ Diamond Intl Corp v Allstate Ins Co, 712 F.2d 1498, 1502 (1st Cir 1983); Assicurazioni Generali SPA v Clover, 195 F.3d 161, 165 (3d Cir 1999); Restatement (Second) of Conflict of Laws $\S 187$, comment a. Incorporations of legal expressions can also display this intent. Restatement (Second) of Conflict of Laws $\S 187$, comment a. Compare section E2(d).

${ }^{11}$ Restatement (Second) of Conflict of Laws $\S 188(2)(\mathrm{e})$. Compare section E1.
} 
case. A court could decide that the references do not display the intention of the parties as to the governing law, or that the Chinese nationality of the parties does not mean that the law of China has the most significant relationship to the contract. Furthermore, a choice of law provision could lead to the application of a law that is different from the connected legal system. ${ }^{12}$

Next, by considering non-governing law when interpreting the contract, a court can give influence to the laws of multiple jurisdictions. The intention of the parties can be influenced by several legal systems. ${ }^{13}$ For example, the intention of Investor and Developer (section B2) could have been influenced by both the law of State $\mathrm{Y}$ and the law of State Z. A conflict of laws analysis must lead to the application of a single law, at least in regard to a single issue. A court may give undue influence to the applicable law when it is not considering whether other laws also influenced the intention of the parties. In contrast, if the non-governing law is just one of the circumstances that influence the interpretation of the contract, the influence of both laws can be considered.

One could argue that this difference is of no importance. After all, even when interpreting a contract, a court must eventually settle on a single interpretation. However, by considering the connections with both jurisdictions, a court is able to give both laws the weight that they are due. For example, if the contract is connected to both the non-governing and the governing law, the court could decide that no single legal meaning had a significant influence on the intention of the parties. In contrast, if the court does not consider the non-governing law, it may assign undue influence to an interpretation in accordance with the governing law.

Similarly, by considering the non-governing law during the interpretation of the contract, a court can interpret different clauses in accordance with different laws without the extensive use of dépeçage. In the contract between the Developer and Investor (section B2), the argument to interpret the term "agricultural market" in accordance with the non-governing law of State $\mathrm{Z}$ is stronger than the argument to interpret the buy-out clause in accordance with this law. After all, the term "agricultural market" has a special relationship with the law of State Z. The buy-out clause does not have such a connection. ${ }^{14}$ In order to reach a result that is in accordance with the intention of the parties, a court may decide to apply the law of State $\mathrm{Z}$ to the interpretation of the term "agricultural market" but apply

\footnotetext{
${ }^{12}$ Dannemann, supra n 6, at 63; Magnus, supra n 5, at 184; V Hagstrøm, "The Nordic Tradition: Application of Boilerplate Clauses under Norwegian Law" in Cordero-Moss (ed) supra $\mathrm{n}$ 5, 265, 267.

${ }^{13}$ D Echenberg, "Negotiating International Contracts: Does the Process Invite a Review of Standard Contracts from the Point of View of National Legal Requirements" in CorderoMoss (ed) supra n 5, 11, 18; G Cordero-Moss, "Does the Use of Common Law Contract Models Give Rise to a Tacit Choice of Law or to a Harmonized Transnational Interpretation?" in Cordero-Moss (ed) supra n 5, 37. Compare section B3.

${ }^{14}$ See section E2(e).
} 
the law of State $Y$ to the interpretation of the buy-out clause. ${ }^{15}$ The text of section 188(1) of the Restatement (Second) of Conflict of Laws seems to allow this result. It states that the rights and duties of the parties with respect to an issue are determined by the law that has the most significant relationship with respect to that issue. Still, the result depends on a detailed division of the issues surrounding the contract. To reach the result, a court must divide the issue of the interpretation of the contract into the more specific issues of the interpretation of single clauses. Although this approach vindicates the intention of the parties, it invites an unnecessarily complicated conflict of laws analysis. ${ }^{16}$ Instead of vindicating the intention of the parties through extensive dépeçage, a court can also give effect to the intention by considering the non-governing law when interpreting the contract. $^{17}$

Furthermore, considering non-governing law during the interpretation of the contract facilitates a clearer and more detailed analysis. An intention to apply the connected law can be distinguished from an intention to interpret the contract in accordance with this law. Similarly, evidence of a general intention to interpret the contract in accordance with the connected law does not necessarily prove that the parties intended to interpret a specific clause in accordance with this law. ${ }^{18} \mathrm{~A}$ conflict of laws approach does not differentiate between these various kinds of intentions. It either applies the connected law or it does not. In contrast, by considering the non-governing law when interpreting the contract, a court can differentiate the influence of the connected law. It can give an influence to this law that is in accordance with the intention of the parties.

Finally, the conflict of laws approach does not explain why the contract should be interpreted in accordance with the connected law. The application of a law does not show that the parties intended an interpretation in accordance with this law. In most cases, the legal meaning of a clause or term in the governing law is of a limited significance. In contrast, voluntary and deliberate connections to the non-governing law strengthen the argument to interpret the agreement in accordance with this law. They can show that the parties intended such an interpretation. ${ }^{19}$

\footnotetext{
${ }^{15}$ Compare Cordero-Moss, supra n 13, at 38 (the use of clauses and models that are connected to a law can be interpreted as a tacit choice of law for that particular part of the contract).

${ }^{16}$ Compare Dannemann, supra $\mathrm{n}$ 6, at 78 (splitting the applicable law to a contract will generally cause more problems than it solves).

${ }^{17}$ About the situations in which dépeçage is appropriate, see generally WLM Reese, "Depecage: A Common Phenomenon in Choice of Law" (1973) Columbia Law Review 58, 60 (dépeçage is appropriate if it effectuates the purpose of the relevant choice of law rules and does not disappoint the expectation of the parties). Dépeçage can be used to give effect to the intention of the parties. This is also the goal of the rules of the restatement. See, e.g. Restatement (Second) of Conflict of Laws $\S 187$, comment a, $\S 188$, reporter's note.

${ }^{18}$ See section E2(f).

${ }^{19}$ See section F7.
} 
This section does not argue that the conflict of laws approach should never be preferred. If the contract contains a choice of law provision or the connected law has the most significant relationship with the contract, a court should apply the governing conflict of laws rules. This section merely shows that, even though a conflict of laws approach can lead to a similar result, considering non-governing law during the interpretation of a contract does have independent value. The "interpretation approach" can give influence to the connected law even if it does not apply under the governing conflict of laws rules. Furthermore, it can give influence to multiple jurisdictions. Finally, it can provide a clearer explanation for the influence of the connected law.

\section{Contract interpretation in the law of the United States}

The interpretation of a contract is about ascertaining the meaning of the expression of the agreement. ${ }^{20}$ It is a three step process. ${ }^{21}$ First, a court determines which statements and agreements actually constitute the judicially enforceable contract. ${ }^{22}$ Next, the court determines whether the contract is ambiguous. A contract or term is "ambiguous" if it is susceptible to more than one reasonable meaning. ${ }^{23}$ The final step consists of the interpretation of the contract proper. After determining

\footnotetext{
${ }^{20}$ Kniffin, supra n 2, at 8; Murray, supra $\mathrm{n} 1$, at 425 . See Kniffin, ibid at $\S 24.3$, for a distinction between interpretation and construction. Most courts use these terms interchangably.

${ }^{21}$ Burton, supra n 1 , at $1-2$.

${ }^{22}$ See EA Posner, "The Parol Evidence Rule, the Plain Meaning Rule, and the Principles of Contractual Interpretation" (1998) University of Pennsylvania Law Review 533, 541-542. This step is not a part of the interpretation of the contract proper. It is about identifying the subject matter of interpretation. Restatement (Second) of Contracts § 213, comment a; Kniffin, supra n 2, at 104-105; Burton, supra n 1, at 63. During this step, the parole evidence rule plays an important role if the contract is in writing. About this rule, see UCC $\S 2-202$; Restatement (Second) of Contracts $\S 213$; Burton, supra n 1, at 64; P Linzer, Corbin on Contracts, supra n 2, 8 and 25-26.

${ }^{23}$ Jacobs v Pickands Mather \& Co, 933 F.2d 652, 657 (8th Cir 1991); McAbee Constr Inc v United States, 97 F.3d 1431, 1434-1435 (Fed Cir 1996); Columbia Gas Transmission Corp v New Ulm Gas Ltd, 940 S.W.2d 587, 589 (Tex 1996); Insurance Adjustment Bureau Inc v Allstate Ins Co, 588 Pa. 470, 481 (2006); Kniffin, supra n 2, 33-34; Burton, supra $\mathrm{n}$ 1, at 106. This step is omitted under the Restatement (Second) of Contracts. Restatement (Second) of Contracts $\S 202$, comment a; Kniffin, supra $\mathrm{n}$ 2, at 34; Burton, ibid, at 139-140; Linzer, supra n 22, at 40-41. It is also omitted under the Uniform Commercial Code. UCC § 2-202, comment 1; Hessler v Crystal Lake Chrysler-Plymouth Inc, 338 Ill. App. 3d 1010, 1021 (2003); Kniffin, ibid, at 35; Burton, ibid, at 140-141; LINZER, ibid, at 42-43. However, applicable state law may still impose a requirement to find an ambiguity. Linzer, ibid, at 43-47. During this step, the "plain meaning rule" and the "four corners rule" play important roles. About these rules, see Indem Ins Co of N Am v Du Pont, 292 F.2d 569, 574 (5th Cir 1961); Fairbourn Commercial Inc v Am Hous Partners Inc, 94 P.3d 292, 295 (Utah 2004); Intermountain Eye \& Laser Centers PLLC v Miller, 142 Idaho 218, 222 (2005); Mundey v Erie Ins Grp, 167 Md. App. 444, 452 (2006); Saleh v Farmers Ins Exch, 133 P.3d 428, 434 (Utah 2006); Burton, ibid, at 109, 111; Linzer, ibid, at 29.
} 
that an ambiguity exists, it is necessary to resolve this ambiguity and attach a meaning to the ambiguous contract or clause. ${ }^{24}$ Different courts have different views about what circumstances may be considered relevant at each of these steps. Burton divides these attitudes into three theories: literalism, objectivism and subjectivism. ${ }^{25}$ A court may employ a different theory in each of the steps. ${ }^{26}$

The first theory is literalism. "Literalism requires interpretation according to the literal meaning of the directly applicable words used in a contract, without taking into account their context." ${ }^{27}$ Under literalism, only the words of the contract and a dictionary influence the interpretation of the contract. ${ }^{28}$ This excludes non-governing law as a relevant circumstance. However, even though a court may state that it applies literalism (the literal meaning of the contract) during one of the steps of contract interpretation, it may still employ circumstances that should not be considered under literalism proper. ${ }^{29}$

For example, in Swiss Bank Corp v Dresser Indus Inc, the court stated that "Delaware follows the plain meaning rule of contract construction which instructs courts to rely solely on the clear, literal meaning of the words if a contract is clear on its face". ${ }^{30}$ However, the very next sentence stated that an "unambiguous integrated written contract should be construed in the way that an objective, reasonable third party would understand it." This sentence indicates that other circumstances may be considered relevant, even if the contract is unambiguous. After all, a reasonable third party may consider the whole document, the purpose of the contract and its context. ${ }^{31}$ Next, courts that follow literalism may still employ the "whole contract" as a relevant circumstance. ${ }^{32}$

\footnotetext{
${ }^{24}$ Burton, supra $\mathrm{n} 1$, at 151 .

${ }^{25} \mathrm{Ibid}$ at 2 . A court may also employ a mix of these theories. Ibid. at 17.

${ }^{26} \mathrm{Ibid}$ at 2. Compare Friendswood Dev Co v McDade \& Co, 926 S.W.2d 280, 282-283 (Tex 1996); Ahsan v Eagle Inc, 287 Ill. App. 3d 788, 791 (1997). In these cases, the court employed an objective approach while determining whether an ambiguity exists, but a subjective approach while resolving this ambiguity. Evidence about the intentions of the parties was not allowed until an ambiguity had been established.

${ }^{27}$ Burton, supra $\mathrm{n} 1$, at $17-18$. This approach is comparable to the "hard-PER" of Posner, supra $\mathrm{n} 22$, at 534 .

${ }^{28}$ Burton, ibid at 14,36 .

${ }^{29}$ Ibid at 18-19, 41-42, 123-125. See, eg Air Line Pilots Assn Intl v Midwest Exp Airlines Inc, 279 F.3d 553, 556 (7th Cir 2002) (the court states that it follows a "literalist" approach, but a party can use objective evidence to argue that there is an extrinsic ambiguity); HarperWittbrodt Auto Grp LLC v Teague, M200500203COAR3CV, 2006 WL 2706148, 10-11 (Tenn Ct App20 September 2006) (the court states that the literal meaning of a contract governs its interpretation. However, the language of the contract should be "construed" with reference to circumstances like the intention and situation of the parties).

${ }^{30}$ Swiss Bank Corp v Dresser Indus Inc, 942 F Supp 398, 400 (ND Ill 1996). Example from Burton, supra n 1, at 18-19.

${ }^{31}$ Burton, supra $\mathrm{n} 1$, at 19.

${ }^{32}$ Beanstalk Grp Inc v AM Gen Corp, 283 F.3d 856, 859-860 (7th Cir 2002); Burton, supra $\mathrm{n} 1$, at 19, 41-42. Similarly, the four corners rule is not truly literalist either, as it takes the
} 
The second theory is objectivism. "[Objectivism] looks for the parties' intention as expressed (manifested) in the contract document as a whole and its objective context, but not the parties' mental intentions". ${ }^{33}$ It gives effect to the intention of the parties as understood by a reasonable person, taking various circumstances into account. ${ }^{34}$ Under objectivism, various circumstances may be taken into account in addition to those that are allowed under literalism. ${ }^{35}$ Circumstances that may be relevant under objectivism include the whole contract, its purpose, usages and customs, the objective circumstances at the time when the contract was made, ordinary meanings, legal meanings, the course of performance and other objective circumstances. ${ }^{36}$ However, the interpreter cannot consider the subjective intentions of the parties. ${ }^{37}$

The final theory is subjectivism. "[Subjectivism] looks for the mental intentions or knowledge of the parties when they manifested their intentions, taking into account all relevant evidence". ${ }^{38}$ It gives effect to the actual intention of the parties at the time of the formation of the contract. ${ }^{39}$ Under subjectivism, various circumstances may be taken into account in addition to those that are allowed under objectivism. ${ }^{40}$ It attaches relevance to the prior course of dealing, the course of negotiations, testimony by a party about its own intentions, and circumstances bearing on the parties' subjective intentions. ${ }^{41}$

\section{E. The potential influence of non-governing law on the interpretation of contracts}

Under both objectivism and subjectivism, the interpretation of a contract depends on the intention of the parties. The interpretation either depends on the actual intention (subjectivism) or the intention as understood by a reasonable person (objectivism). Under these theories, non-governing law can influence the interpretation of a contract if it affects the intention of the parties.

This section analyzes the potential influence of non-governing law. It explores several situations in which non-governing law can be a relevant circumstance.

\footnotetext{
"contract as a whole" into account. Bethlehem Steel Co v Turner Constr Co, 2 N.Y.2d 456, 460 (1957); Murphy v Duquesne Univ of the Holy Ghost, 565 Pa. 571, 591 (2001); Burton, supra $\mathrm{n} 1$, at $111-112,126$.

${ }^{33}$ Burton, supra $\mathrm{n} 1$, at 2.

${ }^{34}$ Kniffin, supra n 2, at 25; A Barak, Purposive Interpretation in Law (Sari Bashi trans, Princeton University Press 2005) 34; Burton, supra n 1, at 2, 41, 44.

${ }^{35}$ Burton, supra $\mathrm{n} 1$, at 35, 41 .

${ }^{36}$ Ibid at 2, 5, 14, 21-22, 41-51.

${ }^{37}$ Ginsberg v Mascia, 149 Conn. 502, 506 (1962); Barak, supra n 34, at 33-34; Burton, supra $\mathrm{n} 1$, at 2, 5, 51.

${ }^{38}$ Burton, supra $\mathrm{n} 1$, at 2.

${ }^{39}$ Altshuler v Malloy, 388 P.2d 1, 4 (Okla 1963); Barak, supra n 34, at 31; Burton, supra $\mathrm{n}$ 1, at 51 .

${ }^{40}$ Burton, supra $\mathrm{n} 1$, at 35-36, 51-52.

${ }^{41}$ Ibid at 35-36, 51-57.
} 
These situations are grouped in accordance with the type of connection to the nongoverning law. This section starts with situations in which the parties are connected to the non-governing law (section E1). Hereafter, it discusses situations in which the contract is connected (section E2).

This section discusses the influence of non-governing law on the interpretation of contracts. For this reason, the following subsections do not contain detailed conflict of laws analyses. Instead, they assume that the conflict of laws rules lead to the application of a law that is different from the connected law. The relationship between the influence of non-governing law on the interpretation of contracts and the application of the connected law through conflict of laws rules is discussed in section $\mathrm{C}$.

\section{The influence of non-governing law in situations in which the parties are connected to the non-governing law}

In discovering the intention of the parties to the contract, courts are instructed to place themselves in the shoes of the parties. ${ }^{42}$ This approach is followed by both objectivist and subjectivist courts. ${ }^{43}$ Non-governing law can provide a background that affects the way in which the parties formulate and understand their contract. A court that wishes to place itself in the shoes of the parties could consider the nongoverning law that is connected to the parties. ${ }^{44}$

In Shu/Lam ${ }^{45}$ the Dutch Supreme Court (HogeRaad) was faced with the circumstances described in section B1. The lower court stated that Chinese standards were irrelevant because Dutch law governed the contract and its formation. The Supreme Court reversed. It found that, because the parties were Chinese, Chinese standards could influence the way in which the parties interpreted each others' statements and behaviour. Therefore, under Dutch law, ${ }^{46}$ the non-governing Chinese norms could influence the interpretation of the contract.

This case deals with Dutch, and therefore civil, law. However, a common law court that wishes to place itself in the shoes of Shu and Lam could also conclude that their intentions may have been influenced by Chinese norms. Naturally, this circumstance does not by itself establish that Lam should be considered the

\footnotetext{
${ }^{42}$ Eg St Lucie Cnty Bank \& Trust Co v Aylin, 94 Fla. 528, 538 (1927); Fid-Phenix Fire Ins Co v Farm Air Serv Inc, 255 F.2d 658, 660 (5th Cir 1958); Restatement (Second) of Contracts $\S 209$, comment b.

${ }^{43}$ For a distinctly objectivist formulation, see Deloro Smelting \& Ref Co v US, 317 F.2d 382, 386, 387 (Ct Cl 1963); Iconco v United States, 6 Cl. Ct. 149, 155 (1984). For a distinctly subjectivist formulation, see Malloy, 388 P.2d at 4.

${ }^{44}$ Compare Rabel, supra n 8, at 534. Compare HLE Verhagen, Agency in Private International Law: The Hague Convention on the Law Applicable to Agency (Martinus Nijhoff, 1995) 327-328 for similar reasoning in the context of agency.

${ }^{45}$ HR 18 November 1983, NJ 1984, 345 (Shu/Lam).

${ }^{46}$ See HR 13 March 1981, NJ 1981, 635 (Haviltex).
} 
employer. It is just one of the circumstances that are to be considered in the interpretation of the contract. Still, it could support the conclusion that the contract is susceptible to two reasonable meanings, and is therefore ambiguous.

Ha v State $^{47}$ shows that American courts also consider the ethnicity of the involved parties, and the norms that are connected to this ethnicity, when determining the demands that are placed on a reasonable person. Ha and Buu are Vietnamese. One night, Buu started a fight with Ha. He beat him and threatened to kill him during and after the fight. Ha was afraid that Buu would carry out his threat. The next day, he shot Buu in the back. At the trial, Ha claimed that he was acting in self-defence. To support this defence, Ha stated that in Vietnamese culture, public threats are carried out and are to be taken seriously. ${ }^{48}$ The court agreed that Vietnamese culture can be considered in analyzing whether Ha's belief that he faced imminent harm was reasonable. ${ }^{49}$ Nonetheless, the defence was rejected because the threat was not imminent.

The case does not concern the interpretation of contracts or non-governing law. However, it is an example in which the court considers non-governing norms. Furthermore, like the interpretation of contracts, the defence is concerned with subjective perceptions. If a reasonable person can consider the norms that are connected to a foreign ethnicity in the context of a criminal trial, there is no reason not to consider such norms in civil litigation.

In the previous examples, the parties are connected to the non-governing law because of their ethnicity or origin. The examples deal with connections between the non-governing law and natural persons. However, a business can also be connected to a non-governing law. Just like natural persons, the agents of a business may understand the contract or certain terms in the light of the law of their habitual place of business. For this reason, the circumstance that both businesses conduct the majority of their activity in another jurisdiction and/or are incorporated in that jurisdiction can provide an argument for interpreting the contract in accordance with the law of that jurisdiction. ${ }^{50}$

A variation on the case of section B2 can provide an example. Investor and Developer each incorporate and operate a business in State Y. In addition, the law of State $\mathrm{Z}$ applies under the conflict of laws rules of State Y. One of the parties claims that he understood the buy-out clause in the light of the law of State Y. The fact that both parties have strong connections to State Y supports this assertion. It provides an argument to interpret the clause in accordance with the non-governing law of State Y.

Finally, a government entity can be connected to the non-governing law. Like natural persons and businesses, government entities can enter into contracts. Some

\footnotetext{
${ }^{47}$ Ha v State, 892 P.2d 184 (Alaska Ct App 1995).

${ }^{48}$ Ibid at 189 .

${ }^{49}$ Ibid at 195 .

${ }^{50}$ Magnus, supra n 5, at 196-197, 209.
} 
of these entities have the power to create and enforce legal rules. These rules may influence the interpretation and the performance of the contract, even if they do not govern the agreement.

NML Capital $v$ Argentina provides an example. ${ }^{51}$ The facts were as follows. Argentina issued bonds. These bonds contained a pari passu clause. The provision stated that " $[\mathrm{t}]$ he payment obligations of the Republic under the Securities shall at all times rank at least equally with all its other present and future unsecured and unsubordinated External Indebtedness." ${ }^{, 52}$ Argentina defaulted on its loans in 2001. The country attempted to restructure its debt by making two exchange offers. It also passed legislation that prohibited payment under the original bonds.

The parties disagreed about the interpretation of the pari passu clause. Argentina claimed that in a sovereign context, the provision only provides "protection from legal subordination or other discriminatory legal ranking by preventing the creation of legal priorities by the sovereign". 53 The Court of Appeals for the Second Circuit disagreed. It applied the law of New York, and found that the provision also protected against the giving of priority to other payment obligations. Argentina violated this provision by making no payments on the original bonds while simultaneously servicing the restructured debts. Furthermore, the court stated that even if Argentina's interpretation were correct, the legislation would still violate the clause by barring the recognition of New York judgments in Argentine courts. $^{54}$

Argentina violated the pari passu clause by enacting and enforcing legislation. ${ }^{55}$ The non-governing Argentine law did not directly influence the interpretation of the contract. It was not one of the circumstances that affected the determination of the intention of the parties. Instead, it was relevant because it shaped the litigation and created a specific question of interpretation. In $N M L$ Capital $v$ Argentina, the court discussed the interpretation of the pari passu clause because the non-governing law violated the provision. Furthermore, the case shows that the relevance of the non-governing law is affected by the connection between this law and the parties to the contract. The legislation led to the violation of the pari passu clause because it was enacted by Argentina, one of the parties to the contract.

\footnotetext{
${ }^{51}$ NML Capital Ltd $v$ Republic of Argentina, 699 F.3d 246 (2d Cir 2012), cert. denied, 134 S. Ct. 2819 (2013). For more information about this case, see Gregory H Shill, "Boilerplate Shock" (2014) Tulane Law Review 751, 794-796; NA Turchi, note, "Restructuring a Sovereign Bond Pari Passu Work-Around: Can Holdout Creditors Ever Have Equal Treatment?" (2014) Fordham Law Review 2171, 2197-2201.

${ }^{52} \mathrm{NML}$ Capital, ibid at 251.

${ }^{53} \mathrm{Ibid}$ at 258.

${ }^{54} \mathrm{Ibid}$ at 259-260.

${ }^{55} \mathrm{Ibid}$ at 260.
} 


\section{The influence of non-governing law in situations in which the contract is connected to the non-governing law}

A contract can be connected to the non-governing law in various ways. First, the contract may contain an express reference to the non-governing law (section E2 (b)). Next, the agreement may be connected to the non-governing law due to an ineffective choice of law clause (section E2(c)). Furthermore, a contract can incorporate a term or a rule of the non-governing law (section E2(d)). Finally, the agreement may be of a type or form that is connected to the non-governing law (section E2(e)). For each of these connections, the parties may have had a general or a specific intention to interpret the contract in accordance with the non-governing law (section E2(f)). In several of the cases discussed below, the contract is connected to religious rules. Section E2(a) discusses several issues that arise in these situations.

\section{(a) A note on religious contracts}

A contract can be connected to the non-governing law because it is connected to a certain religion. In the United States, a court cannot inquire into religious matters. However, it may still enforce religious contracts if this can be done on "neutral principles". 56 Several cases address the enforcement and interpretation of religious contracts. Specifically, various courts address the legal consequences of Islamic and Jewish marriage contracts. For the purpose of this paper, it is important to note that these religious rules are also laws.

In Israel, Jewish law governs marriages between Jews. ${ }^{57}$ Evidence of the dual (religious and legal) character of such rules can also be found in Minkin v Minkin, Avitzur v Avitzur and Burns v Burns. In these cases, the parties agreed to conform to the provisions of the laws of Moses and Israel. ${ }^{58}$ In other words, the contracts treat the law as both religious and as a part of the legal system of Israel. ${ }^{59}$

\footnotetext{
${ }^{56}$ Minkin v Minkin, 180 N.J. Super. 260, 264 (Ch Div 1981); Avitzur v Avitzur, 58 N.Y.2d 108, 115-116 (1983); Akileh v Elchahal, 666 So. 2d 246, 248 (Fla Dist Ct App 1996); Odatalla v Odatalla, 355 N.J. Super. 305, 309 (Ch Div 2002); Thibodeau v American Baptist Churches of Conn, 120 Conn. App. 666, 673-74 (2010); Light $v$ Light, NNHFA124051863S, 2012 WL 6743605, 3 (Conn Super Ct6 December 2012); LM Warmflash, "The New York Approach to Enforcing Religious Marriage Contracts: From Avitzurto the Get Statute" (1984) Brooklyn Law Review 229, 237-241; A Quraishi-Landes, "Rumors of the Sharia Threat Are Greatly Exaggerated: What American Judges Really Do with Islamic Family Law in their Courtrooms" (2012) New York Law School Law Review 245, 249-250.

${ }^{57} \mathrm{M}$ Elon, "The Sources and Nature of Jewish Law and its Application in the State of Israel - Part III" (1968) Israel Law Review 416, 454.

${ }^{58}$ Minkin,180 N.J. Super. at 262; Avitzur, 58 N.Y.2d at 116; Burns v Burns, 223 N.J. Super. 219, 224 (Ch Div 1987).

${ }^{59}$ But see infra n 80.
} 
The influence of Jewish law in the United States is not limited to the interpretation of marriage contracts. The arbitrators of the New York Diamond Dealers Club resolve disputes that arise in contracts about the sale of diamonds. They do not apply the law of New York or another specific law. Instead, they use established trade rules and customs. However, the non-governing Jewish and common law both influence the decision in complex cases that are not covered by these rules. $^{60}$

Several countries adhere to sharia law to various degrees. ${ }^{61}$ In these jurisdictions, sharia is the governing law. It is not just a source of norms outside of the law. Among other topics, sharia law governs the legal consequences of a marriage. ${ }^{62}$

Various recent state statutes in the United States attempt to limit the influence of foreign, and specifically sharia, law. Currently, the constitutionality of such acts has not been determined conclusively. ${ }^{63}$ The amendment of the Oklahoma constitution bans all consideration of international, and specifically sharia, law. However, an injunction against this amendment is in place. ${ }^{64}$ Other states have

\footnotetext{
${ }^{60}$ L Bernstein, "Opting Out of the Legal System: Extralegal Contractual Relations in the Diamond Industry" (1992) Journal of Legal Studies 115, 125-127, 141, 156-157. As the arbitrators do not apply a specific law, this example does not involve American law in a narrow sense. However, the club is located in New York. Furthermore, appeals to the decisions are decided under New York law by a New York court.

${ }^{61}$ L Ali Khan, "Jurodynamics of Islamic Law" (2008) Rutgers Law Review 231, 273-276; JM Otto, "Introduction: Investigating the Role of Sharia in National Law" in JM Otto (ed) Sharia Incorporated (Leiden University Press, 2010) 18, 44-48; BJ Kelley, "Comment, Bad Moon Rising: The Sharia Law Bans" (2013) Loyola Law Review 601, 606. Note that different Islamic schools of thought or geographic traditions may provide different interpretations of a provision in the sharia.TR Siddiqui, "Interpretation of Islamic Marriage Contracts by American Courts" (2007) Family Law Quarterly 639, 643-644, 651, 654; Otto, ibid, at 23-24. If these differences are relevant for the interpretation of the marriage contract, a court could decide to interpret the contract in accordance with the tradition that is most likely to have affected the intention of the parties. For example, a contract could be interpreted in accordance with the Moroccan tradition if the parties have a Moroccan origin. In these situations, both the contract and the parties are connected to the non-governing law. EC Sharpe, "Islamic Marriage Contracts as Simple Contracts Governed by Islamic Law: A Roadmap for U.S. Courts” (2013) Georgia Journal of Gender and Law 189, 202. ${ }^{62}$ Khan, supra n 61, at 274; JM Otto, "Towards Comparative Conclusions on the Role of Sharia in National Law" in Sharia Incorporated, ibid, 613, 629-630; Kelley, supra n 61, at 603 .

${ }^{63}$ Several authors discuss the constitutionality of these acts: eg, S Topy, "Comment, Sharia Law in the Sooner State and Beyond: How the First Amendment Impacts the Future of Anti-Sharia Law Statutes" (2011) University of Cincinnati Law Review 617, 619-630; K Karseboom, "Note, Sharia Law and America: The Constitutionality of Prohibiting the Consideration of Sharia Law in American Courts" (2012) Georgia Journal of Law and Public Policy; Kelley, supra n 61, at 615-631.

${ }^{64}$ Okla Const art VII, § 1; Awad v Ziriax, 670 F.3d 1111 (10th Cir 2012).
} 
passed laws that only ban the consideration of foreign law when such law would violate (constitutional) rights. ${ }^{65}$

A discussion of the effects and constitutionality of these statutes falls outside of the scope of this paper. However, it is important to note that statutes that only ban the consideration of foreign law when such law would violate certain rights have no effect on the interpretation of contracts or the role of non-governing law therein. A contract is ineffective to the extent that it violates mandatory rules. It is only effective within the legal boundaries set by the governing jurisdiction. ${ }^{66}$ The influence of non-governing law on the interpretation of the contract does not affect these boundaries, and does not make it possible to violate rights that cannot be violated otherwise. ${ }^{67}$

\section{(b) The influence of an express reference to the non-governing law}

A contract can contain an express reference to the non-governing law. For example, the agreement between Developer and Investor (section B2) could state that "agricultural market" is the market that is designated as such in the regulations of State Z. Furthermore, Shu and Lam (section B1) could agree that Lam owes Shu an interest on unpaid salaries equal to the highest rate that is allowed by the Chinese law, and this rate is lower than the maximum rate of State $\mathrm{X} .{ }^{68}$ Only the courts that adhere to the strictest version of literalism would not consider the definition of State $\mathrm{Z}$ or the interest rate that is allowed by the law of China. In the event of an express reference, considering the non-governing law gives effect to the expressly manifested intention of the parties. ${ }^{69}$

In Foubert $v$ Turst (1703), the English High Court of Parliament appears to acknowledge the possible influence of an express reference to non-governing law. Two residents of France form a marriage contract. The relevant provision states that the "intended man and wife shall be joint and common in all goods moveable, and acquisitions immovable, pursuant to the custom of Paris."70 They subsequently move to England. The wife dies, and her relatives claim a part of the inheritance. Their claim is not wholly successful, and they appeal.

\footnotetext{
${ }^{65}$ La Rev Stat Ann § 9:6001; Tenn Code Ann § 20-15-101-106; Az Rev Stat Ann § 123101-3103. For an overview of the various "anti-sharia" statutes, see Kelley, supra n 61, at 612-615.

${ }^{66}$ The public policy of the forum also creates boundaries. A court of State X will not enforce a contract if this would violate the public policy of State X, even if the contract is governed by the law of State Y. See, eg In re Marriage of Dajani, 251 Cal. Rptr. 871, 872 (Ct App 1988).

${ }^{67}$ Cutter v Waddingham, 22 Mo. 206, 1855 WL 5380, 46 (1855); Quraishi-Landes, supra $\mathrm{n}$ 56, at 249-251; "Introduction to Part 3" in Cordero-Moss, supra n 5.

${ }^{68}$ Cutter, 1855 WL 5380, 47; Restatement (Second) of Conflict of Laws $\S 187$, illus 4, 5.

${ }^{69}$ Restatement (Second) of Conflict of Laws $\S 187$, comment c.

${ }^{70}$ Foubert $v$ Turst $[1703] 1$ Bro. P. C. 129, 129. At that time, the custom of Paris was the applicable law in the relevant part of France.
} 
The plaintiffs/appellants admit that the customs of Paris do not bind the parties in England. However, they claim that the words "according to the custom of Paris" only serve to explain "what was meant by the word "community". ${ }^{71}$ The reference to the custom served only to interpret the agreement. The defendant/appellee insists that the reference to the custom was not part of the enforceable contract. It was merely a "declaration" without legal effect. ${ }^{72}$ Furthermore, he argues that the laws of France should not be enforced in England. The court finds for the appellants, but the reasoning is not reported. ${ }^{73}$

In Cutter v Waddingham (1855), the Supreme Court of Missouri addresses a similar question. A husband and a wife form a marriage contract. In this case, the relevant provision stated that "the said future spouses to be one and common in all movable property, and immovable conquests, according to the ancient custom established in this colony". The "ancient custom" was the custom of Paris. However, the contract was governed by Spanish law. Judge Scott makes it clear that this discrepancy is of no consequence: "[t]he defendants do not appeal to the custom of Paris as furnishing the rule of law by which the validity of the contract is to be tested, but as supplying the means, and the only means by which the intention of the parties can be ascertained." 74

The express reference influenced the interpretation of the contract. It did not lead to the application of the custom of Paris. Furthermore, the same result would follow under English law. After all, the desired legal consequences could also be reached by expressly writing out all of the relevant provisions:" $[\mathrm{b}] \mathrm{y}$ the French and Spanish law, in all cases, and by the English law, with rare exceptions, parties to contracts are at liberty to adopt any forms of expression to signify their intentions. They may refer to any document, paper, law, statute, ordinance, custom or usage, domestic or foreign, and the thing thus referred to becomes a part of the contract, with the same effect as if its terms were incorporated into the contract in words. This is familiar learning." 75

In Minkin v Minkin and Burns $v$ Burns, the Jewish marriage contract or "ketuba" contained an express reference to non-governing law. The parties agreed to conform to the provisions of the laws of Moses and Israel. ${ }^{76}$ In Minkin v

\footnotetext{
${ }^{71}$ Ibid at 131. Note that the contract, as reported in the case, does not use the word community. Instead, the words "according to the custom of Paris" could explain what was meant by "joint and common".

${ }^{72}$ Ibid at 132.

${ }^{73}$ Ibid at 132. Bayitch states that the court treated the reference as an incorporation of the non-governing law, see SA Bayitch, "The Connecting Agreement" (1953) Miami Law Quarterly293, 295, at n 15. Davie treats the case as a choice of law issue, see M Davie, "Matrimonial Property in English and American Conflict of Laws" (1993) International and Comparative Law Quarterly 855, 879.

${ }^{74}$ Cutter v Waddingham, 22 Mo. 206, 1855 WL 5380, 42 (1855).

${ }^{75}$ Ibid at 42.

${ }^{76}$ Minkin v Minkin, 180 N.J. Super. 260, 262 (Ch Div 1981); Burns v Burns, 223 N.J. Super. 219, 224 (Ch Div 1987).
} 
Minkin, the parties argue about whether the obligation to give a divorce document or " $g e t$ " is civil and enforceable or religious and unenforceable. The court relies on Jewish law and determines that the obligation is civil. ${ }^{77}$ In Burns $v$ Burns, the parties argue about the circumstances under which the husband is obligated to give such a get. The court uses the laws of Moses and Israel to determine several situations in which this obligation exists. ${ }^{78}$

The cases did not contain an explicit conflict of laws analysis. For this reason, it is possible that the court simply applied Jewish law. However, all issues other than the interpretation of the contract were decided in accordance with the law of New Jersey. For example, in Minkin $v$ Minkin, the court ordered a specific performance of the obligation to secure a get. ${ }^{79}$ Furthermore, in Hurwitz v Hurwitz, the court did address the conflict of laws question. In this case, the parties entered into a "koshuba" prior to their marriage. The contract contained a reference to the laws of Moses and Israel. The court applied the law of New York: "[t]he contract in question, in my judgment, is not to be determined by the provisions of the laws of any foreign state. The agreement was made and executed in the State of New York, by persons who at the time resided there; the property affected by the litigation is located in the State of New York and all the parties to the controversy now live within the State and are amenable to its laws." 80

\section{(c) The influence of an ineffective choice of law provision}

An ineffective choice of law provision may still influence the interpretation of the contract. A slight alteration of the circumstances in section B2 can clarify this point. Developer and Investor insert a choice of law provision, stating that the law of State $Z$ applies to the interpretation of the contract. Under the conflict of laws rules of State $Y$, this clause is invalid. However, the interpretation according to State Z does not violate any laws of State Y.

\footnotetext{
${ }^{77}$ Minkin, 180 N.J. Super. at 265-266.

${ }^{78}$ Burns, 223 N.J. Super. at 225-226.

${ }^{79}$ Minkin, 180 N.J. Super. at 266. See also Avitzur v Avitzur, 58 N.Y.2d 108, 112, 117, 119 (1983); Warmflash, supra n 56, at 235; EF Scoles et al, Conflict of Laws (Thomson/West, 4th edn, 2004) $§ 15.24$, at $n 7$.

${ }^{80}$ Hurwitz v Hurwitz, 216 A.D. 362, 366-367 (NY App Div 1926). The court also addressed the question whether the law of Moses and Israel is actually law. It decided that it was not. "I do not understand that the so-called laws of Moses and Israel are what are known and accepted as 'foreign laws.' The 'foreign laws' recognized by us are those of a foreign state or nation. That calls for 'a people permanently occupying a fixed territory, bound together by common laws, habits, and customs [or by a constitution], into one body politic, exercising, through the medium of an organized government, independent sovereignty and control over all persons and things within its boundaries, capable of making war and peace, and of entering into international relations with other communities." Ibid at 366 . Note that this case was decided in 1926, before the founding of Israel.
} 
By interpreting the agreement in accordance with the law of State Z, a court can give effect to the intention of the parties. After all, this intention to interpret the contract in such a manner is expressly manifested in the contract. Furthermore, the parties could reach the same result by expressly writing out all of the relevant provisions of the non-governing law. ${ }^{81}$ Similarly, an effective choice of law provision can also affect the influence of non-governing law. The choice of the law of State $\mathrm{Z}$ weakens the argument to consider the law of State Y. The choice of law provision can indicate that the parties considered the legal consequences of the contract under the law of State Z. Interpreting a clause according to the law of State $Y$ could violate this intention. ${ }^{82}$

Minkin v Minkin and Burns v Burns also provide examples. The agreement to conform to the provisions of the laws of Moses and Israel can be interpreted as a choice of law provision. Even if a court would render this provision ineffective, it can still be used to determine that the parties intended to include an obligation to provide a "get" in accordance with Jewish law. ${ }^{83}$

The influence of (effective or ineffective) choice of law provisions depends on the circumstances of the case. The parties may choose a law without considering its effect on the interpretation of the contract or a specific clause. ${ }^{84}$ In these cases, the strength of the argument to consider the provision is weaker than in situations in which the law is chosen in order to reach the legal consequences that would follow under that legal system.

\section{(d) The influence of the incorporation of terms and non-governing rules}

A contract can incorporate a legal rule or provision that is taken from a non-governing law. Instead of referring to the law, the contract simply copies the relevant rules. Alternatively, the parties copy a clause or term that has a specific legal meaning in the non-governing law. ${ }^{85}$ These rules or terms may be ambiguous in the law that is governing the interpretation of the contract. If present, a court should consider the intention of the parties (subjectivism) as understood by a

\footnotetext{
${ }^{81}$ Several authors treat this issue as a conflict of laws question. In this approach, an ineffective choice of law provision is treated as effective for the purpose of the interpretation of contracts. WLM Reese, "Power of Parties to Choose Law Governing their Contract" (1960) American Society of International Law Proceedings49, 53; D St L Kelly, "Reference, Choice, Restriction, and Prohibition" (1977) International and Comparative Law Quarterly857, 867-868;LL McDougal III, RL Felix and RU Whitten, American Conflicts Law § 135, at 500 (Transnational Publishers, 5th edn, 2001); Scoles, supra n 79, § 18.3, at 956-957; Restatement (Second) of Conflict of Laws $\S 204$, comment b, d.

${ }^{82}$ Cordero-Moss, supra n 67, at 117.

${ }^{83}$ See Warmflash, supra n 56, at 236-237. The cases are discussed supra, section E2(b).

${ }^{84} \mathrm{Eg}$ Echenberg, supra n 13, at 15; Dannemann, supra n 6, at 63.

${ }^{85}$ Section B2. Compare A Menyhárd, "The East European Tradition: Application of Boilerplate Clauses under Hungarian Law" in Cordero-Moss, supra n 5, 302, 304 ("imported clauses").
} 
reasonable person (objectivism) to give the term or provision the meaning that it would have under the connected law. ${ }^{86}$

The argument to consider the non-governing law is especially strong if the borrowed clause is a "boilerplate" provision. Boilerplate provisions are clauses that are standard in a certain type of contract. ${ }^{87}$ They have no special meaning in the particular contract. Instead, they are used because they lead to a standardized result. For these reasons, boilerplate provisions should be interpreted in a uniform and consistent way. ${ }^{88}$ If the provision originates from a non-governing legal system, the intention of the parties can be vindicated by interpreting the clause in accordance with the standardized result in the connected law. Still, the governing law ultimately determines the interpretation of these terms. ${ }^{89}$

In Cutter $v$ Waddingham, the court discussed the means of interpreting technical terms that are borrowed from French law. It decided that the words conquets, douaire, prefix, preciput and ameublissement can only be interpreted with the aid of French law: "[t]o the ear of a judge of Spanish or English law alone, they are mere gibberish. By the light of the French law, their meaning is plain. $\mathrm{He}$ who, in expounding this contract, lays aside the French law as a sealed book, will put away the only interpreter by which the meaning of its terms can be known.."90

In Shamil Bank of Bahrain EC v Beximco Pharmaceuticals Ltd, the English Court of Appeal was faced with an Islamic finance agreement, a "Morabaha", that contained a choice of law provision which stated that "Subject to the principles of the Glorious Sharia'a, this agreement shall be governed by and construed

\footnotetext{
$\overline{{ }^{86} \text { Reese, supra } \mathrm{n} 81 \text {, at 50-51; Kelly, supra } \mathrm{n} \text { 81, at 858-859, 865-867; Restatement }}$ (Second) of Conflict of Laws $\S 187$, comment c; Restatement (Second) of Conflict of Laws § 204, comment a. About German law, see Rabel, supra $\mathrm{n}$ 8, at 535-536; Dannemann, supra $\mathrm{n}$ 6, at 70, 78; Magnus, supra $\mathrm{n}$ 5, at 189-190. For an example in Italian law, see MC Vettese, "Multinational Companies and National Contracts" in Cordero-Moss, supra n 5 , 20,28 . The division between the intention to apply the connected law during the interpretation of the contract (a conflict of laws issue) and the intent to give a meaning to a certain term in accordance with the non-governing law (an interpretation issue) will not always be clear. Kelly, supra $\mathrm{n} 81$, at 867; Cordero-Moss, supra $\mathrm{n} 13$, at 38-43. The incorporation of legal doctrines can be used as evidence that the parties wanted to apply the connected law. Restatement (Second) of Conflict of Laws § 187, comment a, c; Magnus, supra $\mathrm{n}$ 5, at 183. Again, this paper assumes that the relevant conflict of laws rules led to the application of a law that is different from the relevant law. Finally, see Kelly, supra $\mathrm{n} 81$, for a discussion of this issue in English law.

${ }^{87}$ Sharon Steel Corp v Chase Manhattan Bank NA691 F.2d 1039, 1048 (2d Cir 1982).

${ }^{88}$ Broad v Rockwell International Corp, 642 F.2d 929, 948 (5th Cir 1981); Sharon Steel Corp, 691 F.2d at 1048; Vettese, supra n 86, at 20-23; Magnus, supra n 5, at 187-188, Turchi, supra n 51, at 2190.

${ }^{89}$ Magnus, supra n 5, at 186-188; G Cordero-Moss, "Conclusion: The Self-Sufficient Contract, Uniformly Interpreted on the Basis of its own Terms: An Illusion, But not Fully Useless" in Cordero-Moss, supra n 5, 344, 370; Turchi, supra n 51, at 2189.

${ }^{90}$ Cutter v Waddingham, 22 Mo. 206, 1855 WL 5380, 43 (1855).
} 
in accordance with the laws of England". ${ }^{91}$ The court stated that "foreign law" can be incorporated as a term of the contract. When interpreting such a clause under English law, the court can consider the way in which the provisions are interpreted in the non-governing law. ${ }^{92}$ However, in this case, the unspecified reference to Sharia was repugnant to the choice of English law and therefore meaningless. ${ }^{93}$

In the Dutch case Meyer Europe/PontMeyer,${ }^{94}$ Meyer Europe and PontMeyer disagreed about the interpretation of a share purchase agreement. The contract used the English language, but was governed by Dutch law. It contained an entire agreement clause. Entire agreement clauses are typically used in common law jurisdictions. They have no established function in Dutch law. ${ }^{95}$ In the agreement, the seller (Meyer Europe) indemnified the purchaser for several taxes, but not for taxes "included in the provision in the Interim Accounts for corporate income tax covering the period as of April 1, 1998 up to and including the Economic Transfer Date."

The parties disagree about the interpretation of the words "as of". The lower court stated that "as of" can mean both "from" and "as per/as at", but that the words should be interpreted as "from" in the context of this clause. This conclusion was based on a linguistic or grammatical interpretation. The court stated that several circumstances, and in particular the entire agreement clause, led to the conclusion that this kind of interpretation should play an important role. The Dutch Supreme Court (HogeRaad) did not reverse the decision. It stated that the lower court had used the proper rules of interpretation.

Various authors have pointed out that in common law jurisdictions entire agreement clauses do not affect the interpretation of the contract proper. Instead, they influence the determination of which statements and agreements constitute the judicially enforceable contract. ${ }^{96}$ In other words, they affect the first, and not the third, step of contract interpretation (section D).

In Lundiform $/$ Mexx,${ }^{97}$ the Dutch Supreme Court corrected this discrepancy. Lundiform and Mexx formed an agreement. Lundiform would supply hardware for various Mexx shops. The exact quantity was to be determined by

\footnotetext{
${ }^{91}$ Shamil Bank of Bahrain EC v Beximco Pharmaceuticals Ltd (No1) [2004] 1 WLR 1784, 1787.

${ }^{92}$ Ibid at 1799.

${ }^{93}$ Ibid at 1800.

${ }^{94}$ HR 19 January 2007, NJ 2007, 575 (Meyer Europe/PontMeyer).

${ }^{95}$ HR 5 April 2013, NJ 2013, 214 (Lundiform/Mexx); HN Schelhaas, "Pacta sunt servanda bij commerciële contractanten. Over redelijkheid \& billijkheid en objectieve uitleg bij handelscontracten" (2008) Nederlands Tijdschrift voor Burgerlijk Recht150, 153. Several authors discuss the possible legal consequences of an entire agreement clause in Dutch law. Eg RPJL Tjittes, Uitleg van Schriftelijke Contracten (2009) 88-92; JWA Dousi, "De entire agreement clause naar Amerikaans en Nederlands recht: afbakening, geen uitleg" (2013) Contracteren 126, 132-133.

${ }^{96}$ Eg Schelhaas, supra $\mathrm{n}$ 95, at 152; Tjittes, supra n 95, at 89-90; Dousi, supra $\mathrm{n}$ 95, at 130.

${ }^{97}$ HR 5 April 2013, NJ 2013, 214 (Lundiform/Mexx).
} 
"confirmed forecasts". The contract used the English language, but was governed by Dutch law. It contained an entire agreement clause. Before the formation of the contract, Mexx made several promises that did not become part of the written contract or any of the "confirmed forecasts". The parties disagreed about whether Mexx was obligated to fulfil these commitments. The lower court decided that the prior promises did not bind Mexx because of the entire agreement clause. The Supreme Court reversed. It stated that entire agreement clauses have a specific origin and function in common law jurisdictions. They have no particular meaning in Dutch law. Although the provision could influence the interpretation of a contract, it does not regulate the interpretation of the contract.

Meyer Europe/PontMeyer and Lundiform/Mexx deal with contracts that are governed by Dutch law. However, the cases are also relevant in the context of this paper. First, the interpretation of contracts in Dutch law is not radically different from American law. The circumstances of the case affect the determination of the intention of the parties in both Dutch and American law. ${ }^{98}$

Next, the cases show that non-governing law can have various effects. In Lundiform/Mexx, the court did not decide that the clause should be interpreted in accordance with the connected law. It did not discuss the non-governing law in order to reach a single correct interpretation. Instead, it referred to the connected law to show that the interpretation that was given by the lower court was incorrect. The non-governing law was used to eliminate an interpretation that would lead to results that are in strong contrast with the legal consequences under the connected law.

\section{(e) The influence of the type or form of a contract}

The contract may be of a type or form that is connected to the non-governing law. ${ }^{99}$ For example, the contract between Developer and Investor has the same form as the standard agreements that are used in State Z. Furthermore, the type of the contract, an agreement concerning the development of agricultural machines, is also connected to this state. After all, State $Z$ is the worldwide centre of the development of such machines.

The connection provides an argument for an interpretation in accordance with the connected non-governing law. It can be used to argue that the parties intended such an interpretation. However, the force of this argument may vary depending on the conflict. The argument is stronger if the conflict is about an issue that is specifically connected to the non-governing law. It is weaker if the conflict has no special connection to the non-governing law.

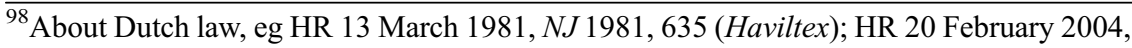
NJ 2005, 493 (DSM/Fox).

${ }^{99}$ Compare G de Nova, "The Romanistic Tradition: Application of Boilerplate Clauses under Italian Law" in Cordero-Moss, supra n 5, 227, 228 (“alien contracts”).
} 
For example, the contract between Developer and Investor contains clauses that are particular to the development of agricultural machines. The clauses containing the terms "competing newly developed machine" and "agricultural market" are only used in contracts about the development of such machines. For these clauses, the argument to consider the law of State $\mathrm{Z}$ is strong. In contrast, the contract also contains clauses and terms that are used in every joint venture contract. For these clauses, the argument to consider the non-governing law is weaker. For example, unless the buy-out clauses are of a type or form that is particular to joint ventures concerning the development of agricultural machines, there is no reason to give much influence to the non-governing law. ${ }^{100}$

In practice, this issue can arise in international commercial transactions. These contracts may be drafted in the English language and use contract models that are developed in common law jurisdictions, even if the contract is governed by another legal system. ${ }^{101}$ However, examples of the influence of non-governing types or forms can also be found in American cases.

Cutter $v$ Waddingham provides an example of the influence of the form of the contract. Judge Scott stated that if, "in taking up the marriage contract, and examining it as a whole, by its parts and its four corners, we recognize it as a formula devised under a particular jurisprudence to accomplish particular purposes, we must have recourse to that jurisprudence to learn the purposes to be accomplished, and in this way become acquainted with the real intention of the parties expressed in the contract." 102 In other words, the non-governing custom of Paris (section E2 (b)) influences the interpretation of the contract when the formula is connected to this law. Furthermore, Scott places emphasis on the purpose of the contract. The argument to consider the connected law is stronger when the form of the contract has been chosen to reach the results that would follow under the connected law.

In addition to "normal" contracts whose type or form is connected to the nongoverning law, a contract can also be connected to another legal system because it is connected to a certain religion. As stated in section E2(a), various courts discuss the legal consequences of Jewish and Islamic marriage contracts. The circumstance that the parties elect to enter into a Jewish or Islamic marriage contract

\footnotetext{
${ }^{100}$ See Magnus, supra $\mathrm{n}$ 5, at 200-202 about this issue under German law.

${ }^{101}$ Eg Vettese, supra $\mathrm{n} 86$, at 20; Dannemann, supra $\mathrm{n}$ 6, at 62; Cordero-Moss, supra $\mathrm{n}$ 67, at 115-116; Magnus, supra n 5, at 179, 187; Cordero-Moss, supra n 89, at 347. See also n 86; section E2(d).

${ }^{102}$ Cutter v Waddingham, 22 Mo. 206, 1855 WL 5380, 43 (1855). For another example, see AJ Le Cras, The Laws, Customs, and Privileges, and their Administration, in the Island of Jersey; with Notices of Guernsey; Also a Commentary on Certain Abuses, and a Petition to Parliament for Reform of the Same (Longman \& Co, 1839) 233.Le Cras also places emphasis on the connection between the contracting parties and the non-governing law (section E1). He discusses an example in which a marriage contract was made by a domiciled Scotsman in the Scottish form.
} 
indicates intent to be bound by Jewish or Islamic law. ${ }^{103}$ An interpretation in accordance with these laws may help to vindicate this intent.

In Odatalla $v$ Odatalla, ${ }^{104}$ a man and a woman formed a "mahr" agreement, an agreement connected to an Islamic marriage. In this agreement, the man promised to pay the woman one golden coin prompt and $\$ 10,000$ postponed. ${ }^{105}$ After the divorce, the woman demands the unpaid sum of $\$ 10,000$. The parties disputed the meaning of the word "postponed". The man states that the contract is too vague to constitute an enforceable contract. The court disagrees. It finds that the woman offered evidence that "postponed" means that the sum would be payable at any time that she demanded it, but that Islamic custom prescribes that the demand is only made in the event of a death or divorce. ${ }^{106}$ The court refers to Islamic custom. However, this custom is a part of the sharia. It is binding in the jurisdictions in which sharia law governs matters of family law.

In Rahman v Hossain,${ }^{107}$ the parties disputed the legal consequences of a mahr or "sadaq". In this case, the man had already paid the full amount to the woman. However, he demanded a refund after the divorce. The court granted this refund. It relied on expert testimony that stated that, under Islamic law and customs, the payment and retention is contingent upon neither party having fault that leads to the termination of the marriage. ${ }^{108}$ The court further relied on Islamic law to find that the woman was at fault. ${ }^{109}$

In these cases, there was no explicit conflict of law analysis. This leaves open the possibility that the court was applying Islamic law and was not merely using it to interpret the agreement. Note, however, that Rahman $v$ Hossain refers to New Jersey rules for other issues such as the validity of the marriage and certain procedural rules. ${ }^{110}$ Similarly, Odatalla $v$ Odatalla relied on a New Jersey case to establish the validity and formation of the contract. ${ }^{111} \mathrm{Next}$, in Aziz $v$ Aziz, the New York court held that the mahr was enforceable because it conformed to the requirements of the (New York) General Obligations Law $\S$ $5-701(\mathrm{a})(3) .^{112}$

\footnotetext{
${ }^{103}$ Compare OT Mohammedi, "Sharia-Compliant Wills: Principles, Recognition, and Enforcement" (2012) New York Law School Law Review 259, 285 (arguing that religious arbitration is the best way to vindicate the intention of the parties).

${ }^{104}$ Odatalla v Odatalla, 355 N.J. Super. 305 (Ch Div 2002).

${ }^{105}$ Ibid at 308. About this case and "mahr" agreements, see generally Siddiqui, supra $\mathrm{n} 61$, at 650 .

${ }^{106}$ Ibid at $312-313$.

${ }^{107}$ Rahman v Hossain, A-5191-08T3, 2010 WL 4075316 (NJ Super Ct App Div, 17 June 2010).

${ }^{108}$ Ibid at 1 .

${ }^{109}$ Ibid at 2.

${ }^{110}$ Ibid at $1,4$.

${ }^{111}$ Odatalla v Odatalla, 355 N.J. Super. 305, 312 (Ch Div 2002).

${ }^{112}$ Aziz v Aziz, 127 Misc. 2d 1013, 1013-1014 (NY Sup Ct 1985).
} 
(f) The intention to interpret a contract in accordance with the non-governing law can be general or specific

In the previous sections, it is assumed that the parties to the contract intended an interpretation in accordance with the connected non-governing law. However, such intent may not exist. The parties may have had an interpretation in mind that is different from the interpretation under the connected non-governing law. For example, even if the parties include an ineffective choice of law provision (section E2(c)), they may not have considered the interpretation of a specific clause according to that non-governing law. Similarly, the Investor and Developer might have casually adopted the standard contract and terms from State Z (sections E2(d) and E2(e)). They may not have thought about the definition of "agricultural market" or the fact that this term might have different meanings under the laws of State $\mathrm{Y}$ and State $\mathrm{Z} .{ }^{113}$

This does not mean that the non-governing law is of no consequence. The nongoverning law still provides an argument for a certain interpretation. After all, a connection with the non-governing law makes it more likely that the parties intended an interpretation that is in accordance with this law. For example, an ineffective choice of law clause indicates that the parties generally intended the legal obligations that would follow under the chosen law, even if they did not consider the meaning of a specific clause. Similarly, parties may incorporate a term or rule because of the expectation that this term or rule leads to satisfactory and workable legal obligations. Such an expectation can be influenced by the interpretation of these terms or rules in the connected non-governing legal system, even if the parties did not consider the exact legal consequences. Again, this provides an argument that the parties generally intended an interpretation in accordance with the non-governing law, even if they did not expect a specific interpretation.

Evidence of a general intention to interpret the contract in accordance with the non-governing law can influence the interpretation of a contract. For example, it can be used to argue that a certain clause is reasonably susceptible to more than one interpretation. However, the influence of the non-governing law will be limited. Further proof of the actual intention (subjectivism) or the intention as understood by a reasonable person (objectivism) may be required to actually adopt this interpretation. ${ }^{114}$

In contrast, if it is possible to show that the parties intended to interpret a specific clause in accordance with the non-governing law, the influence of the non-governing law is greater. For example, further evidence can support the argument that the parties incorporated a specific provision in order to reach the specific

\footnotetext{
${ }^{113}$ Magnus, supra $\mathrm{n} 5$, at 192.

${ }^{114}$ Compare Magnus, supra n 5, at 191-192, 196-197, 208-209 (under German law, the use of a common law contract form does not lead to the interpretation of the contract in accordance with English or American law by itself. Similarly, it should not be regarded as a tacit choice of law); Cordero-Moss, supra n 89, at 350.
} 
result that would follow under the non-governing law. In these situations, the argument to interpret the clause in accordance with the non-governing law is strong.

\section{F. The relation between non-governing law and other circumstances that influence the interpretation of contracts}

In the current literature on the interpretation of contracts, the influence of several relevant circumstances has been analyzed. ${ }^{115}$ This section explores the relationship between several of these circumstances and non-governing law.

Some circumstances can show that the parties intended an interpretation in accordance with the non-governing law. The non-governing law can influence the interpretation "through" other circumstances like the contract as a whole (section F1), its purpose (section F2), the course of performance (section F3), the prior course of dealing (section F4) and the course of negotiations (section F5). This provides an argument for the influence of non-governing law. If nongoverning law can influence the interpretation of a contract "indirectly" through other circumstances, there is no reason to deny "direct" influence.

Other circumstances influence the interpretation of the contract in a way that is similar to the influence of non-governing law. Considering non-governing law is not fundamentally different from considering usages and customs (section F6) or legal meanings (section F7). These circumstances also provide an argument for the influence of non-governing law. If these circumstances routinely influence the interpretation of a contract, there is no reason to categorically exclude the consideration of non-governing law.

This section shows that non-governing law has a clear connection to several of the more established circumstances that influence the interpretation of a contract. However, this does not mean that the recognition of the influence of non-governing law on the interpretation of contracts is without independent value (F8).

\section{The contract as a whole}

Contract clauses are not read in isolation. A contract should be read as a whole and interpreted in the light of its general purpose. ${ }^{116}$ This circumstance is relevant in situations in which the contract as a whole is connected to the non-governing law. Such a connection can exist in the situations that are discussed in section E2. It can exist because of express references to non-governing law (section E2(b)), an ineffective choice of law provision (section E2(c)), multiple incorporations of non-

\footnotetext{
${ }^{115}$ Eg Kniffin, supra n 2, § 24.10, § 24.13, § 24.16-17, § 24.20-21; Burton, supra $\mathrm{n} 1$, at 37-57.

${ }^{116}$ Central Hanover B\& T Co v CIR, 159 F.2d 167, 169 (2d Cir 1947); Sternbergh v Fehling, 396 Pa. 280 (1959); WWW Associates Inc v Giancontieri, 77 N.Y.2d 157, 162-163 (1990); Westmoreland Coal Co v Entech Inc, 100 N.Y.2d 352, 358 (2003); Restatement (Second) of Contracts § 202(2); Kniffin, supra n 2, § 24.21; Burton, supra n 1, at 41-42.
} 
governing rules (section E2(d)) and/or a type or form of contract that is connected to the non-governing law (section E2(e)).

In these situations, the contract as a whole can show that the parties intended an interpretation in accordance with the non-governing law. In most of these situations, the contract as a whole will only display a general intention to such an interpretation. The contract as a whole is less likely to display such an intention in regard to a specific clause. ${ }^{117}$

The contract as a whole can provide evidence of the intention to interpret the contract in accordance with the non-governing law. This is especially relevant if a court only considers a limited number of circumstances when interpreting the contract. In these courts, non-governing law can still exert influence "through" the contract as a whole. After all, even courts that follow literalism may still consider the "whole contract" as a relevant circumstance. ${ }^{118}$

\section{The purpose of the contract}

The purpose of a contract or a clause influences its interpretation. If a shared purpose can be ascertained, it provides a strong argument for an interpretation in accordance with this purpose. ${ }^{119}$ The parties can shape their contract in a certain way for the purpose of reaching the results that would follow under the non-governing law. For example, such a purpose can be manifested through an ineffective choice of law provision (section E2(c)) or by copying a form that is specific to the non-governing jurisdiction (section E2(e)). In these situations, the parties may have had a general purpose of establishing the legal consequences that would follow under the non-governing law. Alternatively, the parties can make specific references to the non-governing law (section E2(b)) or incorporate specific terms and rules (section E2(d)). Such references and incorporations could show the purpose to establish the specific results that would follow under the nongoverning law.

\section{The course of performance}

The course of the performance of the contract influences the interpretation of the contract. ${ }^{120}$ The performance can provide evidence of the parties' intention to interpret the agreement in accordance with the non-governing law.

\footnotetext{
${ }^{117}$ See section E2(f).

${ }^{118}$ Section D, n 32.

${ }^{119}$ Teig $v$ Suffolk Oral Surgery Assocs, 2 A.D.3d 836, 837-838 (NY App Div 2003); Falkowski v Imation Corp, 132 Cal. App. 4th 499, 510 (2005); Restatement (Second) of Contracts $\S 202(1)$; Kniffin, supra n 2, § 24.20; Burton, supra $\mathrm{n} 1$, at 44-45.

${ }^{120}$ Den Norske Bank AS v First Natl Bank of Boston, 75 F.3d 49, 52-53 (1st Cir 1996); Coliseum Towers Associates v Nassau, 2 A.D.3d 562, 564 (NY App Div 2003); UCC § 1-303(a)
} 
For example, assume that the contract between Developer and Investor contains even more clauses that have no special meaning in the law of State Y, but which have been interpreted and defined by the courts and regulatory agency of State Z (section B2). After the formation of the contract, the parties consistently behave in accordance with the meaning that these clauses would have under the law of State Z. This conduct does not just provide an argument for an interpretation of these clauses in accordance with the non-governing law, it is also evidence that the parties intended to interpret other provisions in accordance with the law of State Z.

\section{The prior course of dealing}

The conduct of the parties in similar, prior contracts with each other influences the interpretation of the contract. ${ }^{121}$ Like the course of performance, the prior course of dealing can provide evidence of the parties' intention to interpret the agreement in accordance with the non-governing law.

For example, assume that Investor and Developer have started joint ventures before (section B2). Each of their contracts was strongly connected to the law of another jurisdiction and contained clauses that had a specific meaning in that jurisdiction. In each joint venture, the parties consistently behaved in accordance with the interpretation that these clauses would have under the (governing) law of State Y. This conduct provides an argument against the interpretation of the clauses in accordance with the law of State Z. Alternatively, if the parties consistently interpreted the provisions in accordance with the connected non-governing laws, the argument to consider the law of State $\mathrm{Z}$ would be stronger.

\section{The course of negotiations}

The course of negotiations influences the interpretation of the contract. ${ }^{122}$ The negotiations can show that the parties intended a meaning in accordance with the non-governing law. They can reveal an intention about a specific clause and a general intention to establish the legal consequences that the contract would have under the non-governing law.

For example, Shu asks Lam about the structure of his employment (section B1). Lam answers that all these things are "just like at home". The negotiations

and $\S 2-208(1)$; Restatement (Second) of Contracts $\S 202(5)$; Kniffin, supra $\mathrm{n} 2$, § 24.16; Murray, supra n 1, at 491-493; Burton, supra n 1, at 50-51.

${ }^{121}$ Capitol Converting Equip Inc v Lep Transp Inc 750 F. Supp. 862, 865 (ND Ill 1990); Den Norske Bank AS, 75 F.3d at 52-53; UCC § 1-303(b); Restatement (Second) of Contracts $\S$ 202(5), § 223(2); Kniffin, supra n 2, § 24.17; Murray, supra n 1, at 490-491; Burton, supra $\mathrm{n} 1$, at $52-54$.

${ }^{122}$ Den Norske Bank AS, 75 F.3d at 52-53; Restatement (Second) of Contracts § 202(5); Kniffin, supra n 2, § 24.10, at 64-82; Burton, supra n 1, at 54-56. 
provide a strong argument for the influence of Chinese law in relation to the issue of identifying the employer.

\section{Usages and customs}

Usages and customs influence the interpretation of contracts. A contract can be interpreted in accordance with the relevant usages and customs. ${ }^{123}$ Usages and non-governing law influence the interpretation of contracts in a similar way. Both constitute sets of rules that provide an argument for an interpretation in accordance with these rules. The fact that some sets of rules (usages and customs) can influence the interpretation of contracts suggests that the influence of other sets of rules (non-governing law) is at least possible. It provides an argument for the influence of non-governing law.

However, several differences between usages and non-governing legal rules limit the strength of this analogy. Most importantly, customs and usages are narrowly defined. In UCC $\S 1-303$ (c) and Restatement (Second) of Contracts $\S 222$ (1), a usage of trade requires such a regularity of observance in a place, vocation, or trade as to justify an expectation that it will be observed with respect to the transaction in question. Other definitions are narrower, requiring that both parties know the usage or that they should have known it because it was longstanding, notorious, well-established, and invariable, at the time and place of the formation of the contract. ${ }^{124}$

Non-governing law does not necessarily fulfil these requirements. For example, most restaurants in State $\mathrm{X}$ do not observe Chinese rules (section B1). Even if you apply a narrower trade or vocation, such as the business of running a Chinese restaurant, it can be hard to prove a regular observance that justifies an expectation that it will be observed. At the same time, the parties may not have known the specific Chinese rules. They may just have had a general intention or expectation to contract in a manner that is in accordance with the Chinese rules. $^{125}$

Non-governing law is not just another kind of usage or custom. However, this does not mean that non-governing law cannot influence the intentions or expectations of the parties. Like usages and customs, non-governing law can provide a background that affects the way in which the parties formulate their contract. Even if the contract itself is not connected to the non-governing law, the parties' ethnicity or place of business can influence the way in which the parties

\footnotetext{
$\overline{{ }^{123} \text { Nanakuli Paving \& Rock Co } v \text { Shell Oil Co Inc, } 664 \text { F.2d 772, } 795 \text { (9th Cir 1981); US }}$ Naval Inst v Charter Commns Inc, 875 F.2d 1044, 1048 (2d Cir 1989); Den Norske Bank $A S, 75$ F.3d at 53; Restatement (Second) of Contracts $\S 202(5), \S 220(1)$; Kniffin, supra $\mathrm{n} 2$, $\S 24.13$; Burton, supra $\mathrm{n}$ 1, at 47-48.

${ }^{124}$ SR Intl Bus Ins Co Ltd v World Trade Ctr Properties LLC, 467 F.3d 107, 134 (2d Cir 2006); Burton, supra n 1, at 47.

${ }^{125}$ See section E2(f).
} 
understand the contract (section E1). If a party can provide evidence that the intentions of the parties were affected by the connected law, there is no reason not to consider the non-governing law. ${ }^{126}$

\section{Legal meanings}

The legal meaning of a term as evidenced by a statute or legal precedent influences the interpretation of contracts. It provides an argument to interpret the contract term in accordance with the legal meaning. ${ }^{127}$ In most cases, the contract and the parties are connected to the governing law. This provides an argument for the influence of the legal meaning according to the governing law. However, if the contract or the parties are connected to a non-governing law, the legal meaning according to the non-governing law could influence the intention of the parties.

In most cases, the legal meaning of a term is of limited importance. In the end, it is the intention of the parties that governs the interpretation of the contract. ${ }^{128}$ In many cases, the legal meaning was not known to the parties and did not affect their intentions or expectations. ${ }^{129}$ Section E2(f) explains that a contract that is connected to the non-governing law does not necessarily display an intention to interpret specific clauses in accordance with the non-governing law. However, certain connections can provide an argument for the existence of such an intention. The decision to make a reference to the non-governing law (section E2(b)), include a choice of law provision (section E2(c)) or incorporate a term or rule (section E2(d)) suggests that the parties have put some thought into the legal consequences of the various clauses. In contrast to a "normal" contract that is connected to the governing law, the parties voluntarily and deliberately created a connection with a legal system. This shows that, compared with contracts without a connection to another legal system, the argument to consider the (non-governing) legal meaning is stronger if the contract is connected to non-governing law.

The relevance of voluntary and deliberate connections with a (non-governing) legal system can be illustrated by Frigaliment $v$ Intl Sales Corp. ${ }^{130}$ In this case, a New York corporation sold a large amount of "chicken" to a Swiss corporation. The contract was governed by the law of New York. ${ }^{131}$ The parties predominantly

\footnotetext{
${ }^{126}$ See Kniffin, supra $\mathrm{n} 2, \S 24.8, \S 24.13$, at 116 .

${ }^{127}$ Petula Assocs Ltd v Dolco Packaging Corp, 240 F.3d 499, 503 (5th Cir 2001); Teig v Suffolk Oral Surgery Assocs, 2 A.D.3d 836, 837 (NY App Div 2003); In re Estate of Uzelac, 114 P.3d 1164, 1168-69 (Utah Ct App 2005); Burton, supra n 1, at 48-50.

${ }^{128}$ Della Ratta Inc v Am Better Community Developers Inc, 38 Md. App. 119, 129 (1977); Flintkote Co v General Acc Assur Co, 410 F. Supp. 2d 875, 887 (ND Cal 2006); Restatement (Second) of Contracts $\S 201$, comment c; Burton, supra n 1, at 48-49.

${ }^{129}$ Burton, supra $\mathrm{n} 1$, at 50.

${ }^{130}$ Frigaliment Importing Co v BNS Intl Sales Corp, 190 F. Supp. 116 (SDNY 1960).

${ }^{131}$ Ibid at 118.
} 
communicated in German. However, they used the English word "chicken" instead of the German "Huhn". The buyer claims that this word was used because "chicken" means young chicken whereas "Huhn" can also refer to older "stewing" chicken. He states that the seller should have realized this because its officers were thoroughly conversant with German. ${ }^{132}$

In other words, the buyer claims that the parties deliberately used the word "chicken" in order to avoid the legal consequences that would follow if the parties had used the word "Huhn". This would provide an argument against the interpretation of the word "chicken" in accordance with the meaning of the word "Huhn". Therefore, according to the buyer, "chicken" does not include older birds. The court does not deny the potential influence of the (legal) meaning and avoidance of the word "Huhn". However, Judge Friendly stated that "[w]hatever force this argument might otherwise have" is drained away by testimony that states that the representative of the buyer affirmed that "any kind of chickens", including Huhn, were wanted. ${ }^{133}$ Furthermore, the contract contained a reference to the Department of Agriculture's regulations. The court stated that the contract "made the regulations a dictionary". Under these regulations, "chicken" can also refer to stewing chicken. ${ }^{134}$

After reviewing the evidence, the court concluded that the seller believed that it could comply with the contract by delivering older birds and that this subjective intent coincides with an objective meaning of the word "chicken". The buyer did not prove that "chicken" was used in a narrower sense. Therefore, the seller could fulfil its obligations by delivering stewing chicken. ${ }^{135}$

In Frigaliment, the court considered the influence of two legal meanings on the interpretation of the contract. In both instances, the extent to which the parties voluntarily created a connection with the legal meaning affected its influence. First, the express reference to the Department of Agriculture's regulations increased the relevance of the regulations' definitions. This provided an argument for the interpretation that was proposed by the seller. On the other hand, the inconsistency of the avoidance of the word "Huhn" diminished the influence of the argument. The representative of the buyer affirmed that "Huhn" were wanted. For this reason, there was no deliberate avoidance of this word.

\footnotetext{
${ }^{132}$ Ibid at 118. This knowledge of German makes the relation to the non-governing law less asymmetrical. Compare section B3.

${ }^{133} \mathrm{Ibid}$ at 118 . The buyer and the court do not discuss the legal meaning of the word "Huhn" under any particular non-governing law. However, it is possible that the meaning of the word "Huhn" coincides with its interpretation in legal systems that primarily use the German language. Furthermore, trade usages about the word "Huhn" are more likely to become established in jurisdictions in which the German language is used. The buyer did not only claim to avoid the word "Huhn". He also avoided the legal meaning of this word in the non-governing legal systems.

${ }^{134} \mathrm{Ibid}$ at 120 .

${ }^{135} \mathrm{Ibid}$ at 121 . In addition to the discussed arguments, the court also considered a dictionary, usages and the market prices.
} 


\section{The independent influence of non-governing law}

The previous subsections show that non-governing law has a clear connection to several of the more established circumstances that influence the interpretation of a contract. The non-governing law can influence the interpretation "through" these other circumstances. Again (section C), this raises the question of whether it is necessary to consider the non-governing law when interpreting the contract. Could the consideration of other circumstances lead to the same results?

In this subsection, it will be shown that non-governing law can be associated with the more established circumstances in different ways. The independent influence of the connected law depends on its relation to the other circumstances.

\section{(a) The influence of non-governing law depends on other circumstances}

In some situations, non-governing law influences the interpretation of a contract after the intention to interpret the contract in accordance with the connected law has been established by other circumstances. Cutter $v$ Waddingham provides an example. Judge Scott stated that the contract as a whole (section F1) showed that the marriage contract was devised to accomplish particular purposes (section F2) under the custom of Paris. ${ }^{136}$ The influence of the custom of Paris on the interpretation of the contract was limited to clarifying the legal consequences that would follow under this non-governing law.

In these situations, the intention of the parties cannot be ascertained without considering the non-governing law. However, the influence of the non-governing law depends on other circumstances. The connected law is important because other circumstances established that the parties intended the legal consequences that would follow under this law. The influence of the non-governing law is similar to the influence of a dictionary. A court can use the connected law to determine the meaning of "ameublissement", just as it can use a dictionary to determine the meaning of "chicken". ${ }^{137}$ However, other circumstances may be necessary to establish that the parties intended an interpretation in accordance with the nongoverning law or a dictionary.

\section{(b) Non-governing law affects the influence of other circumstances}

In other situations, no clear sequence between the non-governing law and the other circumstances exist. Instead, the non-governing law and the more established circumstances increase each other's relevance. For example, Lam gave instructions and paid the salary of Shu (section B1). By itself, this course of performance

\footnotetext{
$\overline{{ }^{136} \text { Cutter v Waddingham, } 22 \text { Mo. 206, } 1855 \text { WL 5380, } 43 \text { (1855). See also section E2(e). }}$

${ }^{137}$ Compare Frigaliment, 190 F. Supp. at 121 . In this case, the dictionary did not prove the intention of the parties. It only showed that the interpretation that was advanced by the defendant was reasonable.
} 
does not support the conclusion that Lam was the employer. After all, if Lam acted as an agent for his sister during the formation of the contract, he could also act as an agent during its performance. The non-governing Chinese norms provide the context that is necessary to understand the relevance of the course of performance. Under these norms, the employer is the person that gives the instructions and pays the salary. By performing these actions, Lam acted as if he was the employer.

In these situations, the non-governing law plays an independent role. Its relevance does not depend on other more established circumstances. Instead, the importance of the other circumstances, such as the course of performance, cannot be understood without considering the non-governing law.

It is possible to deemphasize the influence of the non-governing law. For example, a court could use Chinese norms to show that the course of performance supports the conclusion that Lam was the employer. This reasoning suggests that the non-governing law merely affects the interpretation "through" another more established circumstance. Although the reasoning can lead to the same result, it is not very clear. It deemphasizes the circumstance that actually affected the intention of the parties in favour of a circumstance that shows that the parties had a particular intention. Shu thought that he formed a contract with Lam because of the Chinese norms. The circumstance that Lam acted as if he was the employer merely strengthens the argument to consider these non-governing rules. ${ }^{138}$ Instead, the reasoning should reflect the importance of the different circumstances. In this example, the combination of the Chinese norms and the course of performance provides an argument to interpret the agreement in accordance with the non-governing law. By emphasizing the role of the non-governing law, a court can provide a clearer explanation for the conclusion that the contract should be interpreted in accordance with the Chinese norms.

\section{(c) No relation between non-governing law and other circumstances}

Section F deals with situations in which the connected law has a relationship with another circumstance. Such a connection does not necessarily exist in every example of the influence of non-governing law. Furthermore, the relationship between the non-governing law and the other circumstances will not always be clear. In these situations, the connected law has an independent influence on the interpretation of the contract.

For example, section $\mathrm{F}$ discusses several examples of possible connections between the non-governing law and other circumstances in the conflict between Developer and Investor (section B2). However, the non-governing law can also influence the interpretation of the contract without these connections. The fact that the parties incorporated several terms and provisions (section E2(d)) can

\footnotetext{
${ }^{138}$ For more examples in which other circumstances strengthen the argument to consider non-governing law, see sections F3, F4 and F5.
} 
provide an argument for the interpretation of these clauses in accordance with the law of State Z, even if the course of performance (section F3), dealing (section F4) or negotiations (section F5) does not show that the parties intended the legal consequences that would follow under this non-governing law.

The discussed cases also show that a court does not always refer to non-governing law in combination with other more established circumstances. In Foubert $v$ Turst, the non-governing custom of Paris influenced the interpretation of the contract because of an express reference. The case does not point to any other circumstances that increase its importance. ${ }^{139}$ In Lundiform/Mexx, the Dutch Supreme Court used non-governing common law to interpret an incorporated entire agreement clause. The court did not refer to any relationship between the connected law and other relevant circumstances. ${ }^{140}$ Even in Shu/Lam, the influence of the Chinese norms did not depend on the connection with the course of performance. The Dutch Supreme Court simply stated that the Chinese norms could be relevant because the parties were Chinese. ${ }^{141}$

Even in these situations, it is possible to deemphasize the importance of the non-governing law in favour of the more established circumstances. For example, it is possible to argue that the express reference to the custom of Paris in Foubert $v$ Turst, or the incorporation of several terms and provisions in the contract between Developer and Investor, shows that the contract as a whole (section F1) or a single provision was devised to accomplish a particular purpose (section F2). ${ }^{142}$ However, such reasoning is unnecessarily complicated and will not be convincing in all situations.

First, it is unnecessarily complicated because it replaces "intention" with "purpose". In the United States, circumstances influence the interpretation of the contract if they establish the actual intention (subjectivism) or the intention as understood by a reasonable person (objectivism). The purpose of the contract can affect the interpretation. However, the relevance of other circumstances does not depend on their connection with the purpose of the contract.

Next, the reasoning will not be convincing if the references and incorporations are not sufficient to establish a purpose. Non-governing law is just one of the circumstances that can be used to interpret the agreement. Other circumstances could lead to the conclusion that the contract or clause had another purpose or that the purpose is not clear. In these situations, the non-governing law would not influence the interpretation of the contract. By treating the non-governing law as a

\footnotetext{
${ }^{139}$ Foubert $v$ Turst [1703] 1 Bro. P. C. 129, 129; section E2(b). Note that the custom of Paris was the applicable law in the relevant part of France. The court does not refer to "custom" in the sense of section F6.

${ }^{140}$ HR 5 April 2013, NJ 2013, 214 (Lundiform/Mexx); section E2(d).

${ }^{141}$ HR 18 November 1983, NJ 1984, 345 (Shu/Lam); sections E1, F3 and1ANGLE1MSODEL2ANGLE21ANGLE1/MSODEL2ANGLE2 F8(B).

${ }^{142}$ Compare Cutter v Waddingham, 22 Mo. 206, 1855 WL 5380, 43 (1855); section F8(a).
} 
circumstance that directly affects the interpretation, it is possible to consider the connected law in additional situations.

Furthermore, it is possible to stretch the definitions of "usages and customs" and "legal meanings". In this approach, non-governing law would just be another kind of usage or legal meaning. However, this approach deemphasizes several relevant differences between non-governing law, usages and governing legal meanings. ${ }^{143}$ Therefore, it should not be preferred.

To conclude this subsection with a more general point, the fact that it is possible to connect non-governing law with more established circumstances does not lead to the conclusion that the connected law is redundant or that it has no independent influence on the interpretation of a contract. Non-governing law can affect the intention of the parties. It alters the role and influence of several other circumstances. By emphasizing the influence of non-governing law, a court can provide a more convincing motivation for the chosen interpretation.

\section{G. Conclusion}

The interpretation of a contract is about ascertaining the meaning of the expression of the agreement. A court must search for the intention of the parties (section D). This paper answers the following question: "can non-governing law influence the interpretation of contracts?" The previous sections show that a connected nongoverning law can be one of the relevant circumstances that influence the interpretation of a contract.

Non-governing law can be relevant in several situations (section E). First, it is possible that the parties to the contract are connected to the non-governing law. The connected law can provide a background that affects the way in which the parties formulate and understand their contract. A party that is connected to the non-governing law could understand a clause in the light of the legal consequences that the provision would have under the connected law. A court can give effect to the intention of the parties by interpreting the clause in accordance with the nongoverning law. Next, the contract itself can be connected to the non-governing law. For example, the contract could contain an express reference to a non-governing law or incorporate a non-governing rule. Such connections can show that the parties intended the legal consequences that the contract, or a certain clause, would have under the non-governing law.

Non-governing law can also influence the interpretation "through" other circumstances (section F). Some circumstances can show that the parties intended an interpretation in accordance with the non-governing law. For example, the "contract as a whole" and the "purpose of the contract" are circumstances that can influence the interpretation of a contract. The contract as a whole can manifest a purpose to reach the results that would follow under the non-governing law.

${ }^{143}$ See section F7 and F8. 
Moreover, the influence of non-governing law is not significantly different from the influence of several more established circumstances. Considering nongoverning law is not fundamentally different from considering usages and customs. Like non-governing law, usages and customs constitute sets of rules that provide an argument for an interpretation in accordance with these rules.

Finally, certain connections with the non-governing law, such as an express reference, an incorporation of a non-governing rule or a choice of law clause, suggest that the parties have put some thought into the legal consequences of the various clauses. In contrast to a "normal" contract that is connected to the governing law, the parties voluntarily and deliberately created a connection with a non-governing legal system. This shows that, compared with contracts without a connection to another legal system, the argument to consider the (non-governing) legal meaning is stronger if the contract is connected to non-governing law.

Notwithstanding these arguments, the influence of non-governing law on the interpretation of a contract is minor. It is limited to situations in which the relevant conflict of laws rules do not lead to the application of the connected law or in which the contract is connected to several jurisdictions (section C). However, within this limited scope, the ability to consider non-governing law is a useful tool that allows a court to better vindicate the intention of the parties. 